\title{
Adolescent's Sexual Behavior Trends: Describing Father's Parenting Styles and the Impact Towards Academic Success
}

\author{
Yusmansyah $^{1}$ Diah Utaminingsih ${ }^{2} \quad$ Budi Kadaryanto $^{3 *}$ \\ 1.Department of Guidance \& Counseling Education, University of Lampung, Bandarlampung, Indonesia \\ 2.Department of English Education, University of Lampung, Bandarlampung, Indonesia
}

\begin{abstract}
Fathers had an important role for adolescents so that adolescents could avoid premarital sexual behavior. This study aims to determine the level of relationship between fathers and adolescents towards the tendency of free sexual behavior and its impact on academic achievement tendency. This study was a mixed research method using survey and interview methods. The research sample was 283 semester 2 and 4 students who had dated or were dating. Samples were selected using proportional sampling. Data were collected using a questionnaire and the interview protocol. Data were analyzed using descriptive quantitative analysis. The results showed that the lower the relationship between fathers and female adolescents, the greater the chance for the tendency of teenage free sexual behavior. The tendency of sexual activity experienced by adolescents was also high and had an impact on the unsatisfactory academic achievement.
\end{abstract}

Keywords: father's parenting, adolescent, sexual behavior, academic success.

DOI: $10.7176 /$ RHSS/11-16-01

Publication date:August $31^{\text {st }} 2021$

\section{Introduction}

The problem of sexual behavior in adolescents is a global research issue, because although biologically adolescents are mature and capable of reproducing, free sex behavior among adolescents can lead to a variety of long-term negative consequences. Biological maturity causes adolescents to have sexual urges, which results in the emergence of adolescent interest in matters relating to sexual problems and also attraction to the opposite sex (Demidova et al., 2019; Gafos et al., 2019; Ostridge \& O'Connor, 2020; Pringle et al., 2017). If adolescents engage in risky sex then they are likely to experience pregnancy (Dupas et al., 2018; Rashid \& Mwale, 2016). This condition requires them to immediately make a decision and of course it is very difficult for her, namely whether to continue the pregnancy and become young parents or immediately end the pregnancy by having an abortion (Zenebe \& Haukanes, 2019). In addition, adolescents who engage in risky sex also tend to lead to the transmission of sexually transmitted diseases including HIV / AIDS (Ajide \& Balogun, 2018; Cluver et al., 2016). Apart from the health side as mentioned earlier, sexual behavior in adolescents can also disrupt school activities (Simmons, 2017), where free sex activities affect academic success and adolescent involvement in academic activities (Frisco, 2008).

According to data from the Indonesian Demographic and Health Survey in 2017, it shows that around 2\% of female adolescents aged $15-24$ years and $8 \%$ of male adolescents of the same age range, have had sexual relations before marriage. In addition, as many as $11 \%$ of them admitted having an unwanted pregnancy. (health.detik.com.2018). Furthermore, based on the results of a survey conducted by the Adolescent Reproductive Health Survey also states that the percentage of women and men aged 15-24 years who have not been married and have had premarital sexual relations, namely for women aged $15-19$ years by $0.9 \%$, women aged 20-24 years as much as $2.6 \%$ while in males aged $15-19$ years as many as 3.6\% and aged 20-24 years as much as $14.0 \%((\mathrm{BKKBN}), 2018)$.

Related to the findings outlined earlier, the family aspect was very important to anticipate adolescent sexual behavior problems, because the family was the first and foremost educator for their children (Ajayi \& Somefun, 2019; Aspy et al., 2007; Barry \& Harris, 2019; Lenciauskiene \& Zaborskis, 2008). Observations of most families in Indonesia generally provide clear instructions that the father's role as head of the family is often focused only on efforts to meet the financial needs of the family, while the task of educating and caring for children is a matter for the mother (Hanum, 2017), consequently the mother's role is often used as benchmark against the good or bad development of adolescents (Widiarnita, 2012). However, if traced, fathers also make important contributions to the development of children (Fabiano \& Caserta, 2018), the experience shared with fathers will affect a child until adulthood (Heath et al., 2017). The role and behavior of parenting fathers influence the development and well-being of children and the transition to adolescence (Ibrahim et al., 2017).

Several studies had identified the role of fathers and how the relationship of fathers and children to the development of a child's personal life (Akram et al., 2019; Favez et al., 2019; Rodríguez Ruíz et al., 2019). More specifically, the results of the study showed that children without fathers seem to be more at risk of engaging in free sex than those with more stable family backgrounds (Freeman \& Almond, 2010). There are still many studies that reveal how the role of fathers in the sex lives of adolescents (Bowling \& Werner-Wilson, 2000; 
Huebner \& Howell, 2003; Kalina et al., 2013; Wight et al., 2006). However, some of these studies were more likely to reveal how the role of fathers in a short period of time to the teenage sex life, for example the role of fathers at the age of the child in adolescence. However, there had been no research that reveals how the relationship between father and daughter since childhood on adolescent sexual behavior is based on a track record of adolescents' memories and perceptions. Moreover, no one has linked the relationship between the two variables to academic success achieved by students, whereas academic demands in higher education are far more difficult and achievement of academic success in higher education is likely to be influenced by several factors, one of which is student self-control in directing goals his life. Therefore, our study aims to describe the relationship between the role of fathers and the sexual behavior of adolescents through daughter's life experiences memories, and their impact on academic success tendencies achieved

\section{Methods}

This study was a mixed research method (Creswell et al., 2003) with survey research methods (Dyer, 2006). The subjects of this study were female students in semester 2 and 4 who had experience dating or dating, using proportional sampling techniques (Etikan \& Bala, 2017) to obtain 283 students from public and private universities. The researcher compiled the father and adolescent relationship test instrument on adolescent free sex behavior and its impact on the tendency of academic success, with stages were: (1) identify aspects of the independent variable that is the role of the father, and the dependent variable is the tendency of teenage free sex behavior; (2) look for indicators and sub-indicators of the father's role variables and female adolescent free sex behavior. For the role of the father indicator consists of stages of infants to toddlers, pre-teenage stages to adolescents, the influence of fathers on self-esteem, the influence of fathers on romance, while for the inclination of adolescent free sex behavior, the indicators were; romantic relationships, holding hands, kissing, viewing pornography shows, making out and having sex; and (3) Identify the academic achievement of the respondent through grade-point average. The data in this study were analyzed using quantitative descriptive techniques (Combs \& Onwuegbuzie, 2010) which were used to analyze data by describing or describing data that has been collected as it is without intending to make conclusions that apply to the general or generalization.

\section{Findings And Discussion}

We identify the findings based on two research focuses, namely about how the relationship of fathers with female adolescents towards free sex, then about the direct or indirect impact of the relationship between the two variables on academic success achieved by the teenager in college. The academic success that we mean in this study is about the level of student academic achievement which is traced based on the acquisition of cumulative achievement indexes and the tendency for improvement (Morrison \& Morrison, 1995).

\subsection{Findings}

Before we investigate the perceptions of female adolescents regarding their father's relationship and the sexual behavior she had experienced, we firstly reviewed the track record of the father and adolescent's relationship from childhood until she was a teenager based on the memories of the teenager during her lifetime. The first review we conducted was about female adolescents' perceptions about their relationship with fathers from childhood to toddlers based on their memory or track record of life experiences, then the review was continued on adolescent perceptions of their relationship with fathers from the pre-adolescent to teenage stages. The results of data analysis can be seen in Figure 1.

Stage II (Pre-adolescent to Adolescent)

Stage I (Childhood to Toddlers)

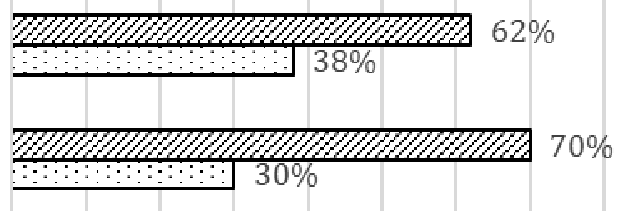

$0 \% \quad 10 \% \quad 20 \% \quad 30 \% \quad 40 \% \quad 50 \% \quad 60 \% \quad 70 \%$ 80\%

\section{O Inharmonious $\mathbf{0}$ Harmonis}

Figure 1. The Level of Harmony between Father and Daughter

Based on the results of a survey related to Figure 1 in the stages from toddlers, we found that only $30 \%$ of teenagers in tertiary institutions felt valued where their existence was really wanted, as teenagers know well that both parents were involved in raising children, and fathers have time with family just to play or joke around. Meanwhile, $70 \%$ of daughters feel their existence were undesirable, and they felt ignored. This was because the father has no time to just play, gather with family. Furthermore, in the stages of adolescence, the results showed 
that the harmony of adolescent relationships with fathers was at a small percentage. Harmonious condition at this stage was marked by the role of fathers who seek to build trust between father and daughter. The condition was also marked by the child wants a story with the father, the father wants to share information and advice about the relationship of the opposite sex when the child enters adolescence, the father respects the child and vice versa, and the role of fathers in helping children when having problems.

In the following review, we emphasized the role of fathers in shaping daughter's self-esteem and the role of fathers in adolescent romance based on the memories of adolescents during life. Findings were presented in Figure 2.

Figure 2. Father's Role and Concern for Female Adolescent Self-Esteem and Romance

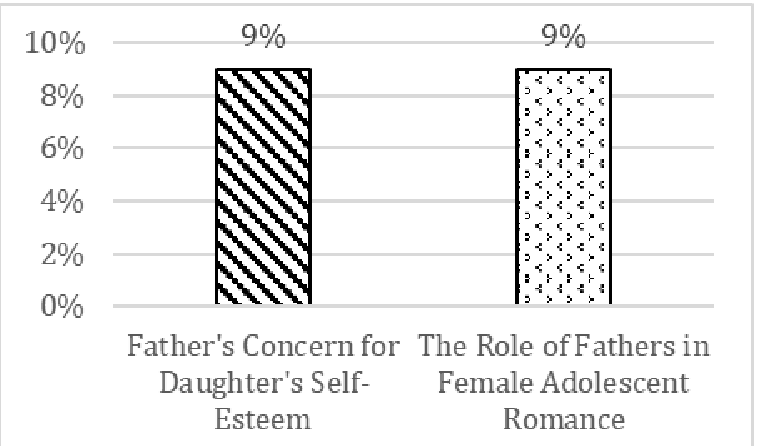

Based on the results of a survey related to Figure 2, the data shows that the role of fathers in the formation of children's self-esteem was classified as low, the evidences revealed that the percentage of the number of adolescents who felt that their father cares about their self-esteem was very low. The level of concern in this aspect was marked by fathers trying to encourage when daughters have problems, want to listen to stories, want to engage in hobby activities, and were able to build self-confidence of daughter. Furthermore, similar data were also found on aspects of the role of fathers in female adolescent romance. The percentage of teenagers who felt their father was involved in their love life also showed a small number. The involvement of fathers in their love life was marked by providing information about the lives of female adolescents, so that teens know what should be done to avoid negative behavior when deciding to date. While almost all adolescents show negative responses related to father involvement in their love life, they stated that their boyfriends were the people who felt they understand the most about their lives, so dating tends to be more open to talking about sex.

Furthermore, the results in the previous point turned out to have an impact on adolescent sexual behavior. The results of data analysis and survey results showed that female adolescents who receive minimal attention from fathers tend to make it easier for adolescents to engage in free sex. This was evidenced by data describing adolescent sexual activity, which consists of holding hands, hugging, kissing, masturbation, premarital sex, and holding breasts/genitals. Free sex activity was in the high category which means that sexual activity was very frequent, the medium category which means that sometimes sexual activity was carried out and was in the low category which means never having sexual activity. The details were explained in more detail in Table 1 . Table 1 explained the closeness of fathers and adolescents who were minimal, providing opportunities for adolescents to engage in free sex

Table 1. Female Adolescent's Experiences of Premarital Sexual Behavior Length Weight of Sections

\begin{tabular}{|c|c|c|c|c|}
\hline \multirow[b]{2}{*}{ No } & \multirow[b]{2}{*}{ Item } & \multicolumn{3}{|l|}{ Category } \\
\hline & & $\begin{array}{l}\text { Low intensity with } \\
\text { high father's } \\
\text { concern }\end{array}$ & $\begin{array}{l}\text { Medium } \\
\text { intensity with } \\
\text { less father's } \\
\text { concern }\end{array}$ & $\begin{array}{l}\text { High intensity } \\
\text { with no } \\
\text { father's } \\
\text { concern }\end{array}$ \\
\hline 1 & $\begin{array}{l}\text { Affected after watching video/movie related to } \\
\text { dating/sex and influenced the way in treating } \\
\text { boyfriend/partner }\end{array}$ & $3 \%$ & $9 \%$ & $88 \%$ \\
\hline 2 & Hold hands with boyfriend/partner & $29 \%$ & $16 \%$ & $54 \%$ \\
\hline 3 & Hugging boyfriend/partner & $10 \%$ & $17 \%$ & $73 \%$ \\
\hline 4 & $\begin{array}{l}\text { Kiss the cheek or forehead of } \\
\text { boyfriend/partner }\end{array}$ & $2 \%$ & $4 \%$ & $94 \%$ \\
\hline 5 & Hugging and kissing for a long time & $5 \%$ & $13 \%$ & $82 \%$ \\
\hline 6 & Often fantasize with a boyfriend to masturbate & $2 \%$ & $3 \%$ & $96 \%$ \\
\hline 7 & Frequent sexual relations without marriage ties & $64 \%$ & $6 \%$ & $30 \%$ \\
\hline 8 & $\begin{array}{l}\text { Have held breasts and rubbed each other's } \\
\text { genitals while still wearing clothes }\end{array}$ & $1 \%$ & $2 \%$ & $97 \%$ \\
\hline
\end{tabular}


Apart from the questionnaire, we also conducted interviews with several respondents who were willing without coercion from researchers who had indeed engaged in sexual activity. The results of the interview can be seen in Table 2.

Table 2. Interview Results

\begin{tabular}{|c|c|c|}
\hline No & Aspect Revealed & Interview Results \\
\hline 1 & $\begin{array}{l}\text { Affected after } \\
\text { watching } \\
\text { video/movie related } \\
\text { to dating/sex and } \\
\text { influenced the way } \\
\text { in treating } \\
\text { boyfriend/partner }\end{array}$ & $\begin{array}{l}\text { - Subject } 1 \text { stated that she rarely communicated with her father. Only } \\
\text { the necessary things discussed. The usual sentences used to ask for example } \\
\text { "What is your grade at school". } \\
\text { - Subject } 2 \text { stated that she had never discussed personal matters with } \\
\text { her father. } \\
\text { - Subject } 3 \text { stated that she preferred to talk with her friends, afraid to } \\
\text { tell her father } \\
\text { - } \\
\text { her father, more chatting with mother. } \\
\text { - Subject } 5 \text { stated that she often heard her father talking rudely to her } \\
\text { mother. This made her less like her father, even though she did not dare to be } \\
\text { frank. }\end{array}$ \\
\hline 2 & $\begin{array}{l}\text { ng and kissing } \\
\text { ong time }\end{array}$ & $\begin{array}{l}\text { Subject } 1 \text { stated that when she was hugged, she felt comfort, so far, } \\
\text { she did not get it from her father figure } \\
\text { - } \quad \text { Subject } 2 \text { stated that she had not been accompanied by her father } \\
\text { since elementary school, so she said she did not know what it was like to be } \\
\text { hugged by dad. When hugged by a boyfriend feels something that had never } \\
\text { been felt so far. } \\
\text { - Subject } 3 \text { stated that she wants to be hugged and kissed because she } \\
\text { thought it was normal for people who were dating. } \\
\text { - } \quad \text { Subject } 4 \text { stated that she was initially scared but she enjoyed and so } \\
\text { far, had never told anyone. }\end{array}$ \\
\hline 3 & $\begin{array}{l}\text { Have held breasts } \\
\text { and rubbed each } \\
\text { other's genitals } \\
\text { while still wearing } \\
\text { clothes }\end{array}$ & $\begin{array}{l}\text { - Subject } 1 \text { stated that she really enjoyed the sensation until she had an } \\
\text { orgasm. } \\
\text { - } \quad \text { Subject } 2 \text { stated that she did it to find pleasure, sometimes relieving } \\
\text { boredom because of the problem at hand. } \\
\text { - Subject } 3 \text { stated that once tried she felt addicted, even wanted to feel } \\
\text { doing it directly. } \\
\text { Subject } 4 \text { stated that she never got information or exchanged ideas } \\
\text { about good and bad men with her father, so she felt that her boyfriend was the } \\
\text { best man so that what was asked was given. } \\
\text { - Subject } 5 \text { stated that she did admit to loving her boyfriend. When she } \\
\text { had a problem, she felt her boyfriend was the only one who could be able to } \\
\text { understand her. }\end{array}$ \\
\hline
\end{tabular}

After obtaining the results that the father's care and role were negatively correlated to the intensity of sexual activity undertaken by female adolescents, we continued to identify the academic achievements of the female adolescent who still acted as students. The results of data analysis related to academic achievement obtained by students related to the relationship of the role of fathers to sexual activity of students were presented in Figure 3. 


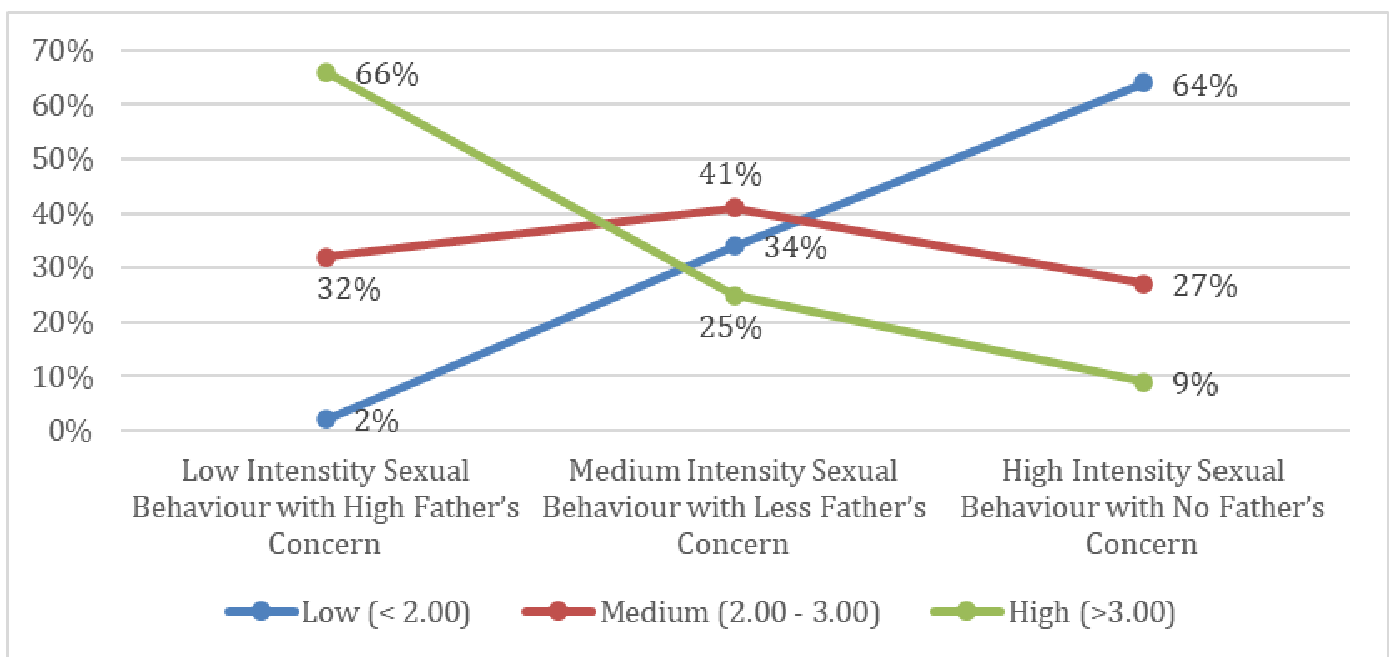

Figure 3. Student's Academic Achievement Based on Grade-Point Average

Figure 3 showed that low adolescent sexual activity that was influenced by a high father's role is apparently positively correlated to student academic achievement, where the student cumulative achievement index tends to be high. If traced during the last two semesters, an increase in student academic achievement could be seen in Figure 4

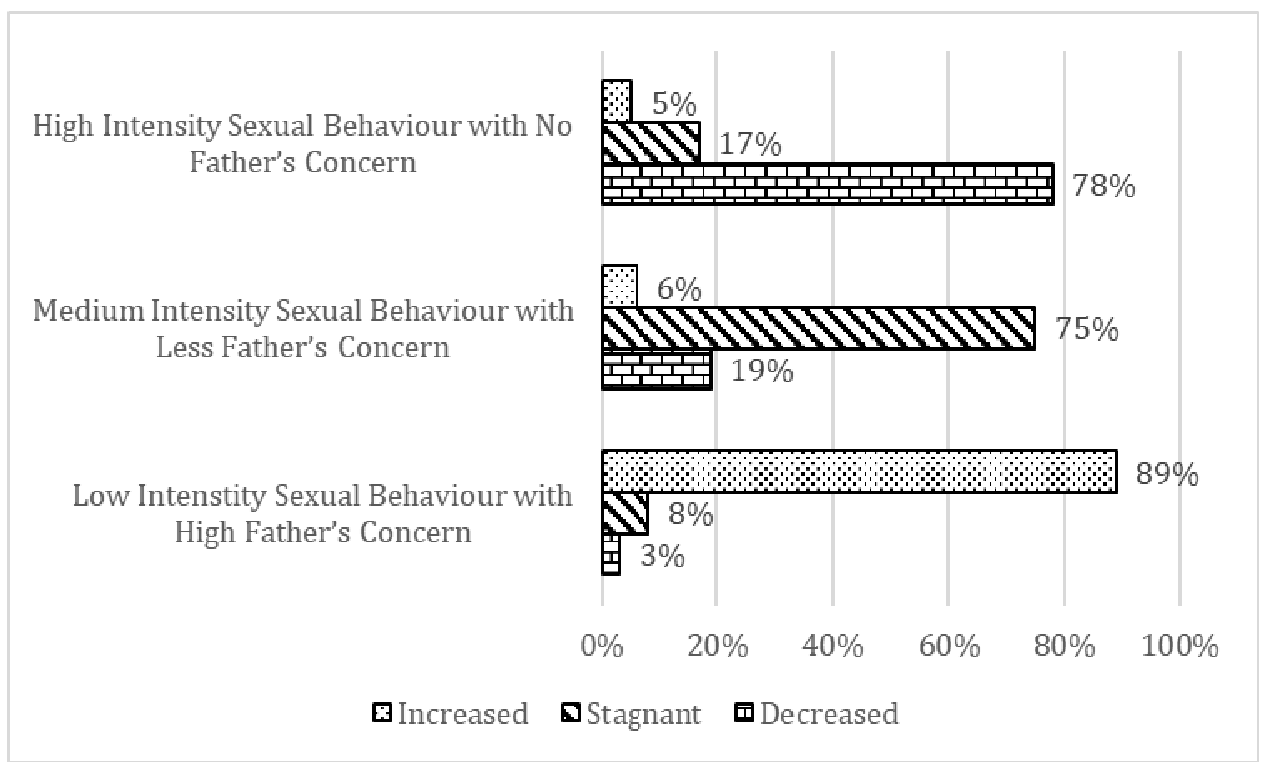

Figure 4. Student's Academic Improvement Category of Two Last Semester

Based on Figure 4, without looking at other factors outside the focus of research, the number of female students who had experienced an increase in academic achievement were they who never had engaged in sexual activity and they were supported by a great concern for their fathers. That is, there were indications that an increase in student academic achievement could be influenced by sexual activity and the role of fathers in their lives.

\subsection{Discussion}

In the process of one's own development, not only mothers who have a great influence on the development of children. Fathers played an important role in shaping the way they think about their environment, friends who can later be applied as adults (Lamb, 2004; Van Lissa et al., 2019). Based on Figure 1, female adolescents who had positive memories related to their relationship with the father since she was a child until she was a toddler stated that the father was involved in care and was willing to provide time to play with her when she was a child. They make their father as an example for their lives, especially in finding a partner, even though their perspective was different (Joeg \& Sriram, 2019). Vice versa, teenagers who had a less harmonious relationship based on the memories of his childhood, stated that her father was less involved in caring for her as a child, this was because her father was busy at work so he have no time to play/joke with the family became minimal. This makes father figure not as a role model in choosing a partner.

According to the results of a survey analysis of daughter's perceptions of the harmonious relationship with 
their father, it appears that as teenagers step up (Figure 1), the attention of the father to her tends to increase the relationship was more harmonious, but the increase was not so significant compared to the psychological development of the adolescent so rapidly (Alexander, 2017; Bbck, 1982; Kleinemeier et al., 2010). The need for care and attention from a father in her teenage years is indeed much greater than when she was a child, because in her teens age will face an environment that required her to interact with friends, especially the opposite sex. Various conflicts could arise in a child as a teenager, starting from the search for identity until the determination of the future. However, what happens to students was that most of them feel that they get less attention when they are teenagers.

There was a relationship between father's presence in the child's personal life, reinforced from the results of data analysis which showed that daughters without fathers appear to be more at risk in free sex than those who come from more stable family backgrounds, although there was no relationship between father's absence and sexual life of students (Golombok, 2014). This interpretation was strengthened by the evidence that of 283 students, there are 81 no father students tend to engage in improper dating behavior, such as hugging, and kissing for a long time, even as many as 74 students claiming unable to live without boyfriend. Daughters who live without fathers tend to lack self-control and were unable to maintain their self-esteem as women (Frazier \& Cowan, 2020; Keizer et al., 2019).

Fathers have a very big role in building daughter's confidence, so they were more courageous when they were in the social environment. The results showed that students who feel that their father did not care about their self-esteem find it difficult to get close to their father, more easily influenced by friends in terms of dating style. The lack of a father's level of concern for the daughter in relation to building her self-esteem seems to be directly related to the sexual behavior or activity that was done during adolescence. This was shown by the evidence that those who do not get the attention of their fathers tend to be "indifferent" to their self-esteem. They have the perception that they only need to be happy and have a place to lean on, so when undergoing a relationship, they don't think too much about the risks that lead to free sex.

Overall the survey results have shown that the role of fathers was very low in terms of love relationships, which results in daughter lacking trust in their fathers, and were reluctant to share problems with their fathers, not even making their fathers as role models in finding a life partner even in terms of sexual behavior free they were more loose to do free sex. They felt her father was too strict in terms of rules and they felt that her family did not care about her, assuming the boyfriend knew and understood her best. The problems mentioned above indicate the low role of fathers in their involvement in building children's self-esteem (Zia \& Ali, 2018). The role of fathers contributes to the occurrence of adolescent free sex behavior that becomes laxer and easily influenced by their social environment. In line with the theory which states that fathers who were too strict or loose in terms of rules, allow adolescents to run the risk of courtship and even risk bad for their health, such as reproductive health problems (Ellis et al., 2003). The results of this study indicated that there was a possibility that the relationship between parents and children also provides experiences in children about adult relationships and sexual relations in the future. Children who were often affected by problems at home and rarely get the attention of their fathers, will tend to feel insecure and seek love outside the home. This is what triggers more easily they have free sex.

If analyzed in depth, there will be a harmonious tendency between the relationship between the role of fathers and the sexual activity that adolescents have experienced towards the tendency of achieving academic achievement (see Figures 3 and 4). The survey results show that students who have a harmonious relationship with their father tend to have good resilience and struggle in academic matters. They stated that they did not want to make his father disappointed, because all this time they considered his father as a role model. They stated that they would make every effort to achieve good academic performance and be able to make their father proud. They even stated that 'dating' was not a good thing because it would only waste time, energy, and thoughts, besides that they had the perception that they had to maintain their dignity and honor as a woman. There is no picture in their minds for sexual activity that leads to free sex. They use more time to learn and develop themselves through organizations, so that academic achievement obtained is also more optimal. This finding leads to the conclusion that the attention and concern of fathers to their self-esteem and love life from childhood to teenage indications have an impact on academic achievement and adolescent achievement. This was in line with research by Gözü and Zia et al. which shows that the relationship between father and daughter influences the child's self-esteem, which is also related to the child's academic achievement (Gözü, 2019; Zia et al., 2015). Children who have a harmonious relationship with their father, will have better self-control, which affects their academic struggle. However, the percentage of students who fall into this category is still smaller than the percentage of students who are in opposition, so there needs to be a solution to overcome this problem in future research.

Intended to give interpretation and meaning to the results of the study in accordance with the theories and references that are used. It is not merely used to present findings. Interpretation should be enriched with referencing, comparing, or contrasting with findings of previous research published in reputable, not predatory, 
journal. It is advisable to integrate findings into collection of theories or established knowledge, development of a new theory, or modification of existing theories. Implications of the research findings are given.

\section{Conclusion}

The results of research with quantitative data analysis show that the higher the role of fathers in the lives of daughters, the lower is involved in the tendency of female adolescent free sex behavior. Fathers who were not involved in building a daughter's self-esteem, make them easily influenced by the social environment, and make her boyfriend as a place to complain. The minimal role of fathers was involved dynamically in a adolescent's love relationship, causing they have a more lenient tendency to engage in free sex. The hypothesis, the better the relationship between fathers and female adolescents, the smaller the tendency of adolescent free sex behavior was proven by the research conducted. In addition, the relationship between father and daughter influences the adolescent's self-esteem, which was also related to their academic achievement. Children who have a harmonious relationship with their father, will have better self-control, which affects their academic struggle. Based on the overall results of this study, the researcher gave a number of suggestions, including being expected to foster better, continuous and cooperative relationships with children's parents, even needing to be scheduled for regular meetings to discuss child development. In terms of education, Father also plays a very important role in the adolescent development, so that now there was a need for intense cooperation with mothers related to adolescent development, for the sake of adolescent's safety in the future. There is a need for research related to techniques for students who have already had free sex, so that the next can better control their dating behavior.

\section{References}

(BKKBN), B. K. dan K. B. N. (2018). Survey Demografi dan Kesehatan Reproduksi Remaja 2017 Kesehatan Reproduksi Remaja.

Ajayi, A. I., \& Somefun, O. D. (2019). Transactional sex among Nigerian university students: The role of family structure and family support. PloS One, 14(1), e0210349.

Ajide, K. B., \& Balogun, F. M. (2018). Knowledge of HIV and intention to engage in risky sexual behaviour and practices among senior school adolescents in Ibadan, Nigeria. Archives of Basic and Applied Medicine, $6(1), 3$.

Akram, M., Batool, Z., Mahmood, B., \& Mahmood, S. (2019). Role of Father in Child Personality Development: Evidence from Pakistan. European Online Journal of Natural and Social Sciences: Proceedings, 8(3 (s)), pp-1.

Alexander, T. (2017). Children and adolescents. Transaction Publishers.

Aspy, C. B., Vesely, S. K., Oman, R. F., Rodine, S., Marshall, L., \& McLeroy, K. (2007). Parental communication and youth sexual behaviour. Journal of Adolescence, 30(3), 449-466.

Barry, S., \& Harris, E. (2019). The children's programme: a description of a group and family intervention for children engaging in problematic and harmful sexual behaviour and their parents/carers. Journal of Sexual Aggression, 25(2), 193-206.

Bbck, J. H. (1982). Psychological development of female children and adolescents. Women: A Developmental Perspective: Proceedings of a Research Conference, 82, 107.

Bowling, S. W., \& Werner-Wilson, R. J. (2000). Father-daughter relationships and adolescent female sexuality: Paternal qualities associated with responsible sexual behavior. Journal of HIV/AIDS Prevention \& Education for Adolescents \& Children, 3(4), 5-28.

Cluver, L. D., Orkin, M. F., Yakubovich, A. R., \& Sherr, L. (2016). Combination social protection for reducing HIV-risk behavior amongst adolescents in South Africa. Journal of Acquired Immune Deficiency Syndromes (1999), 72(1), 96.

Combs, J. P., \& Onwuegbuzie, A. J. (2010). Describing and illustrating data analysis in mixed research. International Journal of Education, 2(2), 1.

Creswell, J. ., Plano Clark, V., Gutman, M., \& Hanson WE. (2003). Advanced mixed methods study designs. In: Tashakkori, A, Teddlie, C (eds), Handbook of Mixed Methods in Social \& Behavioural Research. Thousand Oaks, CA: Sage.

Demidova, L. Y., Murphy, L., Dwyer, R. G., Klapilová, K., \& Fedoroff, J. P. (2019). International review of sexual behaviour assessment labs. International Review of Psychiatry, 31(2), 114-125.

Dupas, P., Huillery, E., \& Seban, J. (2018). Risk information, risk salience, and adolescent sexual behavior: Experimental evidence from Cameroon. Journal of Economic Behavior \& Organization, 145, 151-175.

Dyer, C. (2006). Research in Psychology: A Practical Guide to Methods and Statistics. Blackwell publishing. http://books.google.co.uk/books?id=5iYO4h-NLV4C

Ellis, B. J., Bates, J. E., Dodge, K. A., Fergusson, D. M., John Horwood, L., Pettit, G. S., \& Woodward, L. (2003). Does father absence place daughters at special risk for early sexual activity and teenage pregnancy? Child Development, 74(3), 801-821. 
Etikan, I., \& Bala, K. (2017). Sampling and sampling methods. Biometrics \& Biostatistics International Journal, $5(6), 149$.

Fabiano, G. A., \& Caserta, A. (2018). Future directions in father inclusion, engagement, retention, and positive outcomes in child and adolescent research. Journal of Clinical Child \& Adolescent Psychology, 47(5), 847862.

Favez, N., Tissot, H., \& Frascarolo, F. (2019). Parents' representations of mother-child and father-child relationships as predictors of early coparenting interactions. Journal of Family Studies, 25(2), 199-213.

Frazier, D. M., \& Cowan, R. G. (2020). The Correlation Between Attachment Style, Self - Esteem, and Psychological Well - Being of Fatherless Women Ages 25-55. Adultspan Journal, 19(2), 67-76.

Freeman, H., \& Almond, T. M. (2010). Mapping young adults' use of fathers for attachment support: Implications on romantic relationship experiences. Early Child Development and Care, 180(1-2), 227-248.

Frisco, M. L. (2008). Adolescents' sexual behavior and academic attainment. Sociology of Education, 81(3), 284-311.

Gafos, M., Horne, R., Nutland, W., Bell, G., Rae, C., Wayal, S., Rayment, M., Clarke, A., Schembri, G., \& Gilson, R. (2019). The context of sexual risk behaviour among men who have sex with men seeking PrEP, and the impact of PrEP on sexual behaviour. AIDS and Behavior, 23(7), 1708-1720.

Golombok, S. (2014). Parenting: What really counts? Routledge.

Gözü, H. (2019). Parenting Patterns in Turkey: The associations with Academic Achievement and Self-Esteem.

Hanum, S. L. (2017). Peran Ibu Rumah Tangga dalam Membangun Kesejahteraan Keluarga. Academica: Journal of Multidisciplinary Studies, 1(2), 257-272.

Heath, G., Farre, A., \& Shaw, K. (2017). Parenting a child with chronic illness as they transition into adulthood: a systematic review and thematic synthesis of parents' experiences. Patient Education and Counseling, $100(1), 76-92$.

Huebner, A. J., \& Howell, L. W. (2003). Examining the relationship between adolescent sexual risk-taking and perceptions of monitoring, communication, and parenting styles. Journal of Adolescent Health, 33(2), 7178.

Ibrahim, M. H., Somers, J. A., Luecken, L. J., Fabricius, W. V, \& Cookston, J. T. (2017). Father-adolescent engagement in shared activities: Effects on cortisol stress response in young adulthood. Journal of Family Psychology, 31(4), 485.

Joeg, P., \& Sriram, R. (2019). You Showed Me the Ways of the World: Daughters' Essays on Their Fathers. In Fathering in India (pp. 219-234). Springer.

Kalina, O., Geckova, A. M., Klein, D., Jarcuska, P., Orosova, O., van Dijk, J. P., \& Reijneveld, S. A. (2013). Mother's and father's monitoring is more important than parental social support regarding sexual risk behaviour among 15-year-old adolescents. The European Journal of Contraception \& Reproductive Health Care, 18(2), 95-103.

Keizer, R., Helmerhorst, K. O. W., \& van Rijn-van Gelderen, L. (2019). Perceived quality of the MotherAdolescent and Father-Adolescent attachment relationship and adolescents' self-esteem. Journal of Youth and Adolescence, 48(6), 1203-1217.

Kleinemeier, E., Jürgensen, M., Lux, A., Widenka, P.-M., Thyen, U., \& Group, D. S. D. N. W. (2010). Psychological adjustment and sexual development of adolescents with disorders of sex development. Journal of Adolescent Health, 47(5), 463-471.

Lamb, M. E. (2004). The role of the father in child development. John Wiley \& Sons.

Lenciauskiene, I., \& Zaborskis, A. (2008). The effects of family structure, parent-child relationship and parental monitoring on early sexual behaviour among adolescents in nine European countries. Scandinavian Journal of Public Health, 36(6), 607-618.

Morrison, T., \& Morrison, M. (1995). A meta-analytic assessment of the predictive validity of the quantitative and verbal components of the graduate record examination with graduate grade point average representing the criterion of graduate success. Educational and Psychological Measurement, 55(2), 309-316.

Ostridge, L., \& O'Connor, C. D. (2020). Reporting Unwanted Sexual Behaviour at a Post-Secondary Institution: Student Understandings of Campus Policy. Canadian Journal of Family and Youth/Le Journal Canadien de Famille et de La Jeunesse, 12(1), 225-242.

Pringle, J., Mills, K. L., McAteer, J., Jepson, R., Hogg, E., Anand, N., \& Blakemore, S.-J. (2017). The physiology of adolescent sexual behaviour: A systematic review. Cogent Social Sciences, 3(1), 1368858.

Rashid, S., \& Mwale, M. (2016). The effects of sex education on the risky sexual behaviour of school going adolescents: a case study of Mbenjere secondary, Ntaja and Nsanama community day secondary schools. Psychology and Developing Societies, 28(1), 126-138.

Rodríguez Ruíz, M. M., Carrasco, M. Á., \& Holgado-Tello, F. P. (2019). Father involvement and children's psychological adjustment: Maternal and paternal acceptance as mediators. Journal of Family Studies, 25(2), 151-169. 
Simmons, R. G. (2017). Moving into adolescence: The impact of pubertal change and school context. Routledge.

Van Lissa, C. J., Keizer, R., Van Lier, P. A. C., Meeus, W. H. J., \& Branje, S. (2019). The role of fathers' versus mothers' parenting in emotion-regulation development from mid-late adolescence: Disentangling betweenfamily differences from within-family effects. Developmental Psychology, 55(2), 377.

Widiarnita, G. (2012). Hubungan antara Peran Ibu dalam Komunikasi Ibu-Anak dengan Perilaku Seksual Remaja Putri di SMKN 2 Ponorogo. UNIVERSITAS AIRLANGGA.

Wight, D., Williamson, L., \& Henderson, M. (2006). Parental influences on young people's sexual behaviour: A longitudinal analysis. Journal of Adolescence, 29(4), 473-494.

Zenebe, M., \& Haukanes, H. (2019). When abortion is not within reach: Ethiopian university students struggling with unintended pregnancies. International Journal for Equity in Health, 18(1), 1-13.

Zia, A., \& Ali, S. M. (2018). POSITIVE FATHER AND DAUGHTER RELATIONSHIP AND ITS IMPACT ON DAUGHTER'S INTERPERSONAL PROBLEMS. Journal of Social Sciences and Humanities, 61-68.

Zia, A., Malik, A. A., \& Ali, S. M. (2015). Father and daughter relationship and its impact on daughter's selfesteem and academic achievement. Academic Journal of Interdisciplinary Studies, 4(1), 311. 